\title{
STRATEGI FAKULTAS DAKWAH DAN ILMU KOMUNIKASI DALAM MEWUJUDKAN KAMPUS YANG BERKARAKTER
}

\author{
Fithri Choirunnisa Siregar \\ Institut Agama Islam Negeri Padangsidimpuan \\ (E-mail: fithriandroid@gmail.com)
}

\begin{abstract}
This study aims to determine the strategy of the Padangsidimpuan Da'wah Faculty and Communication Sciences Padangsidimpuan State Islamic Institutein realizing a characteristic campus. In its implementation, this research belongs to the type of descriptive qualitative with ethnometodology approach which conducts field studies on how people from the order of proponents commonly use the traits of order for their citizens to become real organized features. The subjects of this study were members of the FDIK organizational structure of IAIN Padangsidimpuan and students who were members of HMJ from four study programs in the FDIK of IAIN Padangsidimpuan. The data analysis technique uses a qualitative analysis model to obtain data that can describe how organizational members see, explain and describe the systems that already exist within the organization. From the results of the study it was found that in fact character development activities already existed and were running in the Da'wah and Communication Faculty strategically but not had a significant impact on the character development of the academic community so that it needed systemic evaluation to run better.
\end{abstract}

Key words : Strategic, Characterism, Campus

\begin{abstract}
Abstrak
Penelitian ini bertujuan untuk mengetahui strategi Fakultas Dakwah dan Ilmu Komunikasi IAIN Padangsidimpuan dalam mewujudkan kampus yang berkarakter. Dalam pelaksanaannya, penelitian ini termasuk kedalam jenis kualitatif deskriptif dengan pendekatan etnometodologi yang melakukan studi lapangan tentang bagaimana cara masyarakat dari pendukung tatanan yang lazim menggunakan sifat-sifat tatanan bagi para warganya agar menjadi ciri-ciri terorganisasi secara nyata. Subjek penelitian ini adalah anggota struktur organisasi FDIK IAIN Padangsidimpuan dan mahasiswa yang tergabung dalam HMJ dari empat Prodi yang ada di FDIK IAIN Padangsidimpuan. Teknik analisis data menggunakan model analysis kualitative untuk mendapatkan kumpulan data yang dapat menggambarkan bagaimana anggota organisasi melihat, menerangkan dan menguraikan sistem yang sudah ada didalam organisasinya. Dari hasil penelitian ditemukan bahwa sesungguhnya kegiatan pengembangan karakter telah ada dan berjalan di Fakultas Dakwah dan Ilmu Komunikasi secara strategis namun belum memiliki dampak yang signifikan terhadap pengembangan karakter civitas akademika sehingga memerlukan evaluasi yang sistemik agar memperoleh hasil lebih baik.

Kata kunci : Strategi, Kampus, Berkarakter
\end{abstract}




\section{A. Pendahuluan}

Karakter adalah yang utama dari wujud manusia berkualitas. Manusia berkualitas adalah manusia berkarakter yang menjadi salah satu pilar terdepan menopang eksistensi sebuah peradaban, karena bangsa yang memiliki karakter kuat dapat menjadi bangsa yang bermartabat dan mampu berdaya saing dengan bangsa lain di seluruh dunia.

Urgensi dan harapan dalam Pengembangan Karakter sebenarnya telah diamanatkan oleh pendiri bangsa (founding fathers) dan akan terus dikembangkan oleh Pemerintah Indonesia hingga sekarang. Hal ini harus terus dilaksanakan karena memandang semakin merosotnya karakter bangsa yang cenderung meninggalkan karakter dan nilai-nilai budaya negara Indonesia. Efek globalisasi telah membawa generasi penerus estafet perjuangan bangsa kepada "penuhanan" materi sehingga terjadi ketidakseimbangan antara pembangunan ekonomi dan tradisi kebudayaan masyarakat ${ }^{1}$. Semangat bersaing untuk meraih kesejahteraan hidup yang lebih baik telah mengalahkan nilai-nilai kebaikan terhadap diri sendiri bahkan terhadap sesama manusia sebagai bagian dari makhluk sosial sehingga mengalami degradasi karakter disetiap aspek kehidupan masyarakat.

Kondisi merosotnya karakter mahasiswa bangsa Indonesia juga semakin diperjelas pada kalangan mahasiswa dan lulusan pendidikan Tinggi sebagai wujud nyata generasi intelektual dan kelak akan meneruskan estafet pemimpin bangsa termasuk menjadi tenaga pendidik dan kependidikan diberbagai tingkat pendidikan formal. Kemerosotan yang terjadi saat ini disebabkan oleh beberapa faktor diantaranya adalah adanya ketidaksinkronan/ kesenjangan program antara lembaga pendidikan dengan kebutuhan pasar tenaga kerja. Kesenjangan tersebut dikarenakan oleh sistem pembelajaran yang diterapkan di berbagai pendidikan Tinggi saat ini masih berorientasi pada hard skills yakni menyiapkan mahasiswa yang cerdas keilmuan, cepat lulus sesuai target dan segera mendapat pekerjaan walaupun tidak sesuai dengan kualitas kompetensi lulusan.

Khusus untuk pelaksanaan kegiatan pendidikan pada pendidikan tinggi ialah Tridharma pendidikan Tinggi. Semua kegiatan pendidikan, penelitian dan

1 Muslich, Pengembangan Karakter Menjawab Tantangan Multidimensional, (Bumi Aksara, 2011) h. vii 
pengabdian masyarakat, sesungguhnya dapat diwujudkan melalui kebiasaan dalam kehidupan keseharian seluruh masyarakat akademik yang menjadi budaya kampus yang berkarakter. Bentuk nyata dari keberhasilan pendidikan tinggi yang berkarakter adalah apabila kampus yang terdiri dari tenaga pendidik dan kependidikan dapat menyiapkan mahasiswa sebagai generasi muda yang terbiasa memiliki keterampilan dan kebiasaan berpikir kritis, meneliti dan menganalisa, memecahkan masalah, membuat keputusan yang tepat, dan memiliki karakter yang baik (good character) secara tepat dan arif. Dengan demikian, kegiatan keseharian yang berkarakter di kampus dan lingkungan sekitarnya dapat terwujud secara optimal.

Hal ini yang telah diupayakan oleh Fakultas Dakwah dan Ilmu Komunikasi (FDIK) sebagai satu-satunya Fakultas di lingkungan IAIN Padangsidimpuan yang menetapkan mata kuliah Character Building sebagai mata kuliah wajib di Prodi Bimbingan Konseling Islam sejak Tahun Ajaran 2014/2015 hingga sekarang. Selain itu, FDIK juga menetapkan kegiatan ekstrakurikuler kemahasiswaan dengan nama Character Building sejak tahun Ajaran 2014/2015 sebagai salah satu metode untuk menyalurkan potensi minat bakat dan kreatifitas, yang diseimbangkan bersama pendidikan akhlak mahasiswa agar bermanfaat bagi perkembangan karakter secara keseluruhan dan berkesinambungan.

Dalam proses perjalanan kegiatan pengembangan karakter sejak tahun 2014 hingga saat ini, seharusnya pendidikan karakter di Fakultas Dakwah dan Ilmu Komunikasi sudah mampu membina pengembangan karakter yang signifikan seluruh civitas akademika. Hal ini yang sesungguhnya diharapkan oleh organisasi struktural Fakultas Dakwah dan Ilmu Komunikasi bahwa dengan pelaksanaan pengembangan karakter melalui pendidikan tinggi yang bertujuan untuk mengasah potensi minat dan bakat yang ada pada mahasiwa dan sekaligus untuk membina kepribadian mahasiswa ${ }^{2}$. Namun pada kenyataannya belum mengarah kepada perkembangan yang signifikan bahkan cenderung tidak stabil dalam sistem implementasinya.

${ }^{2}$ Nurul A Harahap, Pelaksanaan Kegiatan Character Building, (Skripsi, 2018), h. 
Tentu saja masih belum ideal karena selain karakter individu sendiri pada dasarnya tidak dapat terbentuk secara instan, terlebih untuk kalangan mahasiswa yang menjalani tahap akhir dalam pencarian jati diri sebagai remaja menuju kemapanan kepribadian untuk menjalani masa dewasa. Kondisi ini memerlukan koordinasi yang baik dari organisasi didalam FDIK dalam menyusun kembali strategi secara serius agar dapat mencapai bentuk dan kekuatan yang ideal, ${ }^{3}$ sesuai dengan visi dan misi Fakultas agar selanjutnya dapat mewujudkan kampus yang berkarakter secara efektif, berkelanjutan dan evaluatif.

Berdasarkan pemikiran dan berbagai fakta diatas, menjadi alasan kuat bagi peneliti untuk melakukan penelitian dengan mengangkat judul, "Strategi Fakultas Dakwah dan Ilmu Komunikasi (FDIK) Institut Agama Islam Negeri (IAIN) Padangsidimpuan dalam Mewujudkan Kampus yang Berkarakter”.

\section{B. Rumusan Masalah}

1. Bagaimana perkembangan Pendidikan Karakter di Fakultas Dakwah dan Ilmu Komunikasi IAIN Padangsidimpuan pada saat ini ?

2. Bagaimana Strategi Pengembangan Karakter di Fakultas Dakwah dan Ilmu Komunikasi IAIN Padangsidimpuan dalam Mewujudkan Kampus yang Berkarakter?

\section{Tujuan Penelitian}

1. Mengungkapkan bagaimana perkembangan Pengembangan Karakter Fakultas Dakwah dan Ilmu Komunikasi IAIN Padangsidimpuan hingga saat ini.

2. Mengungkapkan bagaimana Strategi Pengembangan Karakter Fakultas Dakwah dan Ilmu Komunikasi IAIN Padangsidimpuan dalam mewujudkan kampus yang berkarakter.

\section{Kerangka Teoritis}

\section{Karakter}

\section{a. Pengertian}

Untuk mengetahui pengertian karakter, dapat dilihat dari dua sisi pandangan yaitu sisi kebahasaan dan sisi istilah. Menurut bahasa (etimologis), konsep karakter berasal dari bahasa Latin kharakter, kharassaein, dan kharax,

\footnotetext{
${ }^{3}$ Op.cit. h. 29
} 
serta bahasa Yunani character dari kata "karasso", yang berarti "cetak biru", "format dasar", "sidik" seperti sidik jari. Dalam bahasa Inggris character dan dalam bahasa Indonesia lazim digunakan dengan istilah karakter. ${ }^{4}$

Sementara itu, dalam Kamus Besar Bahasa Indonesia (KBBI), pusat Departemen Pendidikan Nasional yang memberikan definisi atas kata karakter yang berarti sifat-sifat kejiwaan, akhlak atau budi pekerti yang membedakan seseorang dengan yang lain, atau bermakna bawaan, hati, jiwa, kepribadian, budi pekerti, perilaku, personalitas, sifat, tabiat, temperamen dan watak.

Maka istilah "berkarakter" artinya memiliki karakter, ciri khas, kepribadian, berperilaku, bersifat, bertabiat, dan berwatak. Individu yang berkarakter baik atau unggul. Istilah "Seseorang yang berkarakter" adalah orang yang senantiasa berusaha melakukan hal-hal yang terbaik terhadap Allah SWT, dirinya, sesama, lingkungan, bangsa dan negara serta dunia internasional pada umumnya dengan mengoptimalkan potensi (pengetahuan) dirinya dan disertai dengan kesadaran, emosi, dan motivasinya (perasaannya). ${ }^{5}$

Pendidikan menjadi cara, metode atau langkah membangun karakter, yang secara implisit mengandung arti membangun sifat atau pola perilaku yang didasari atau berkaitan dengan dimensi moral yang positif atau baik, bukan yang negatif atau buruk. Sistem pendidikan dapat dinyatakan berhasil apabila mampu membentuk manusia berkarakter yang sangat diperlukan dalam mewujudkan sebuah negara kebangsaan yaitu bangsa dan negara Indonesia yang diakui dan berdaulat.

\section{b. Pengembangan Karakter}

Menurut Kemendiknas, Character Building yang didalam Bahasa Indonesia biasa dikenal dengan Pendidikan Karakter adalah usaha untuk menanamkan kebiasaan-kebiasaan yang baik (habituation) didalam dunia pendidikan sehingga mahasiswa mampu bersikap dan bertindak berdasarkan nilainilai yang telah menjadi kepribadiannya melalui pendekatan sistematik dan integratif dengan melibatkan keluarga, satuan pendidikan, pemerintah, masyarakat sipil, anggota legislatif, media massa, dunia usaha, dan dunia industri.

\footnotetext{
${ }^{4}$ Heri Gunawan, Pengembangan Karakter, Konsep dan Implementasi, (Penerbit Alfabeta, 2014), h. 1

${ }^{5}$ Ibid. h. 2
} 
Menurut Lickona, Pengembangan Karakter adalah sebuah upaya yang disengaja untuk mengembangkan kebajikan, Kebajikan dalam diri setiap manusia tidak datang secara tiba-tiba, tetapi memerlukan usaha yang giat dan kuat (Character education is deliberate effort to cultivate virtue-, that is, objectively good human qualities that are good for the individual person and good for whole society. That doesn't happen accidentally or automatically. It happens as a result of great and diligent effort). Dalam prosesnya, Pengembangan Karakter merupakan upaya membentuk/mengukir kepribadian manusia melalui proses pengetahuan kebaikan (knowing the good), mencintai kebaikan (loving the good), dan melakukan kebaikan (acting the good), yaitu proses pendidikan yang melibatkan tiga ranah : pengetahuan moral (moral knowing), perasaan moral (moral feeling/moral loving), dan tindakan moral (moral acting/moral doing), sehingga perbuatan mulia dapat terukir menjadi habit of mind, heart, and hands. Tanpa keterlibatan ketiga ranah tersebut, Pengembangan Karakter tidak akan dapat berjalan dengan efektif.

\section{Strategi}

\section{a. Pengertian}

Strategi berasal dari kata strategic yang berarti rencana yang cermat mengenai kegiatan untuk mencapai sasaran khusus ${ }^{6}$. Secara umum istilah strategi sering dimaknai sebagai garis besar haluan untuk bertindak dalam usaha yang telah ditentukan ${ }^{7}$. Selain itu, strategi merupakan program yang luas untuk mendefinisikan dan mencapai tujuan dari usaha suatu organisasi ${ }^{8}$. Strategi juga dapat diartikan sebagai tanggapan organisasi terhadap lingkungannya sepanjang waktu. Selanjutnya James Brian menerjemahkan strategi sebagai pola atau rencana yang mengintegrasikan tujuan pokok, kebijakan, dan rangkaian tindakan suatu organisasi kedalam satu kesatuan yang kohesif (melekat antara yang satu dengan lainnya/ terpadu).

Sehingga dapat disimpulkan dari beberapa pengertian sebelumnya, bahwa strategi didesain oleh pemimpin/manajemen puncak agar organisasi yang

\footnotetext{
${ }^{6}$ Ibid. h. 15

${ }^{7}$ Ibid. h. 184

${ }^{8}$ Najib dkk., Manajemen Strategik Pendidikan Karakter, (Penerbit Gava Media. Yogyakarta. Cetakan I, 2016), h. 16
} 
dipimpin dapat memiliki daya saing dengan organisasi lain untuk digunakan dalam memperoleh kesuksesan atau keberhasilan dalam mencapai tujuan yang telah ditetapkan.

\section{b. Hubungan Strategi dan Organisasi}

Strategi disusun secara bertahap untuk memastikan agar program yang direncanakan dapat dilaksanakan. Strategi memiliki korelasi yang erat dengan struktur organisasi dan menentukan pengaruh terhadap implementasi strategi. Jika ada perubahan strategi, maka struktur organisasi juga dapat ikut berubah agar strategi dapat dilaksanakan dengan baik. Oleh karena itu, penyusunan strategi harus didesain oleh struktur organisasi ${ }^{9}$, kemudian memberikan lebih banyak perhatian dan menyelaraskan arus keputusan dan tindakan yang mengarah kepada perkembangan strategi yang efektif, evaluatif dan berkelanjutan.

Strategi baru sebatas proses penyusunan rencana (planning) kerja dan belum sampai pada wujud atau tindakan yang nyata. Keputusan penyusunan strategi harus diarahkan kepada pencapaian tujuan terhadap langkah-langkah pembelajaran, pemanfaatan berbagai fasilitas dan sumber belajar dalam bentuk rumusan tujuan. Rumusan tujuan yang baik akan memberikan pengaruh terhadap semua elemen atau komponen pembelajaran yang strateginya kemudian akan diwujudkan melalui implementasi kedalam perilaku yaitu praktek habituasi atau kebiasaan.

Struktur organisasi berhubungan erat dengan kegiatan pengorganisasian. Pengorganisasian merupakan suatu proses untuk merancang struktur formal, mengelompokkan dan mengatur serta membagi tugas-tugas atau pekerjaan diantara anggota organisasi agar tujuan dan sasaran organisasi dapat dicapai dengan efektif dan efisien.

Dalam organisasi terdiri dari banyak sumber daya yang perlu diatur penggunaannya untuk mencapai tujuannya. Oleh karena itu, organisasi perlu dikelola secara tepat, sehingga dikenal dengan istilah manajemen ${ }^{10}$. Abdus Salam mengungkapkan bahwa manajemen merupakan suatu proses yang terdiri dari

\footnotetext{
${ }^{9}$ Najib dkk. Ibid. h. 50

${ }^{10}$ Bangun, Intisari Manajemen, (Penerbit Aditama, 2011), h. 2
} 
serangkaian kegiatan dalam menggerakkan seluruh sumber daya organisasi secara sinergik menuju pencapaian tujuan organisasi secara efektif dan efisien ${ }^{11}$.

\section{c. Unsur-unsur dalam Manajemen dari Strategi}

Abdul Salam mengungkapkan bahwa manajemen merupakan bagian dari strategi organisasi untuk melaksankan suatu proses yang terdiri dari serangkaian kegiatan untuk menggerakkan seluruh sumber daya organisasi secara sinergik menuju pencapaian tujuan organisasi secara efektif dan efisien. Selanjutnya tujuan organisasi dapat dikatakan tercapai secara efektif dan efisien jika apa yang dilakukan oleh anggota organisasi benar-benar sesuai dengan tujuan organisasi yang telah ditetapkan dan mampu meminimalisir peggunaan sumber daya yang dimiliki oleh organisasi sesuai dengan tujuan organisasi yang telah ditentukan ${ }^{12}$.

Unsur-unsur yang terdapat dalam manajemen organisasi meliputi :

1) Sekelompok orang yang tergabung dalam suatu organisasi

2) Serangkaian kegiatan yang mencakup kegiatan perencanaan, pengorganisasian, pelaksanaan, dan penilaian

3) Upaya kerjasama yang dilakukan oleh orang-orang yang ada didalam suatu organisasi

4) Pemanfaatan sumber daya yang dimiliki oleh suatu organisasi

5) Tujuan organisasi yang hendak dicapai, meliputi tujuan jangka pendek dan tujuan jangka panjang.

\section{d. Kegiatan Manajemen Organisasi}

Titik tekan dari manajemen adalah bahwa dalam manajemen terdapat berbagai dimensi teknis yang digunakan untuk mencapai tujuan organisasi ${ }^{13}$. Berbagai dimensi teknis ini yang kemudian diistilahkan dengan kegiatan manajemen, yang meliputi:

1) Perencanaan (planning)

Merupakan proses penentuan tujuan organisasi dan pemilihan tindakan masa depan untuk mencapai tujuan. Perencanaan tersebut meliputi :

a) Penentuan tujuan organisasi

\footnotetext{
${ }^{11}$ Najib dkk. Op.cit. h. 13

12 Ibid. h. 13

${ }^{13}$ Ibid. h. $12-13$
} 
b) Pengembangan premis-premis tentang lingkungan dimana tujuan ingin dicapai

c) Pemilihan tindakan yang hendak dicapai

d) Memprakarsai berbagai aktivitas yang diperlukan untuk menerjemahkan rencana dan strategi agar menjadi tindakan

e) Mengevaluasi hasil perencanaan.

2) Pengorganisasian (organiting)

Merupakan proses yang menghubungan pekerja dan pekerjaannya untuk mencapai tujuan organisasi. Proses ini meliputi :

a) Perumusan kewenangan manajerial

b) Pembagian kerja diantara kelompok dan individu serta mengkoordinasikan aktivitas-aktivitas individual dan kelompok dalam suatu struktur tertentu.

c) Pengembangan staf dan sumber daya manusia yang mengacu pada proses penyeleksian, pengembangan dan memberi penghargaan pada pekerja yang kompeten untuk mencapai tujuan organisasi. Proses ini juga meliputi penciptaan iklim kerja yang kondusif dimana setiap staf atau pekerja merasakan puas sehingga lebih bersemangat untuk melanjutkan pekerjaan lebih baik dari sebelumnya.

3) Pelaksanaan (actuating)

Merupakan proses penginduksian individu atau kelompok untuk dapat melaksanakan tugas dengan baik dan berkerjasama saling saling membantu secara harmonis dalam rangka mencapai tujuan organisasi.

4) Pengawasan atau pengontrolan (controlling)

Sebagai proses untuk menjaga agar tercapainya tujuan organisasi secara efektif dan efisien. Proses ini menyangkut perumusan standar, membandingkan kinerja yang diukur terhadap standar yang telah dirumuskan secara maksimal sebelumnya melalui rapat organisasi, kemudian saling menguatkan berbagai faktor keberhasilan dan mengoreksi kegagalan secara bijaksana.

\section{E. Metode Penelitian}

Lokasi penelitian ini dilaksanakan di lingkungan Fakultas Dakwah dan Ilmu Komunikasi IAIN Padangsidimpuan. Penelitian ini termasuk kedalam jenis 
penelitian kualitatif dalam bentuk deskriptif dengan menggunakan pendekatan etnometodologi yang melakukan studi tentang bagaimana cara orang-orang sebagai pendukung dari tatanan yang lazim menggunakan sifat-sifat tatanan bagi para warganya agar menjadi ciri-ciri terorganisasi yang kelihatan nyata ${ }^{14}$. Penelitian ini juga berupaya menemukan pencapaian kerja yang praktis tentang bagaiamana cara anggota organisasi memandang, menjelaskan dan memberikan tatanan didunianya sendiri.

Sumber data adalah subjek darimana data diperoleh ${ }^{15}$. Sumber data dalam penelitian kualitatif ini adalah sumber data primer dan sekunder yaitu : Sumber data primer, diperoleh melalui teknik wawancara tidak terstruktur. Sumber data primer diperoleh dari subjek (struktural leader) menjadi subyek wawancara dari key person berupa keterangan Dekan FDIK sebagai pembuat keputusan, Wakil Dekan I yang membawahi bidang kurikulum dan silabus perkuliahan, Wakil Dekan III yang membawahi berbagai kegiatan ekstrakurikuler mahasiswa, dan Kepala Bagian Tata Usaha sebagai bagian dari pelaksana teknis dari setiap kegiatan yang berkaitan dengan sarana dan prasarana yang ada di lingkungan kampus.

Disamping itu dilakukan pula wawancara bagi Dosen yang diamanahkan oleh organisasi untuk mengontrol langsung kegiatan character building persemester yaitu Arifin Hidayat, S.Sos.I., M.Pd.I yang berada di bagian Akademik. Untuk keseimbangan informasi yang didapatkan dari wawancara juga dilakukan bersama mahasiswa yang telah direkomendasikan atau ditentukan sebelumnya.

Dan untuk lebih lengkapnya data maka diperlukan pula kegiatan observasi terhadap berbagai proses kegiatan Pengembangan Karakter yaitu perkuliahan character building, kegiatan character building setiap hari rabu pagi dan observasi keseharian kampus FDIK yang berkarakter. Observasi dilakukan dengan melihat aktivitas perkuliahan dan ekstrakurikuler mahasiswa sebagai bagian dari proses manajemen sekaligus bagian dari kurikulum. Kemudian Sumber data sekunder, diperoleh dari berbagai studi dokumen untuk melihat rekam jejak

${ }_{15}^{14}$ Suyanto, Bagong, Metode Penelitian Sosial, (Prenadamedia, 2013), h. 201

15 Arikunto, Prosedur Penelitian Suatu Penelitian Praktis, (Penerbit Rineka Cipta, 2006), h. 10 
perkembangan atas proses perkuliahan dan kegiatan Pengembangan Karakter di lingkungan FDIK IAIN Padangsidimpuan.

Untuk menyajikan data agar mudah dipahami, maka langkah-langkah analisis data yang digunakan dalam penelitian ini adalah Analysis Kualitative Model dari Miles dan Huberman, yang membagi langkah-langkah dalam kegiatan analisis data dengan beberapa bagian yaitu pengumpulan data (data collection), reduksi data (data reduction), penyajian data (data display), dan penarikan kesimpulan atau verifikasi (conclutions).

Berikut panduan proses kegiatan analisa data:

1. Dari hasil wawancara, observasi, pencatatan dokumen, disusun catatan lapangan yang lengkap. Terdiri dari deskripsi dan refleksi.

2. Kemudian dibuat reduksi data berupa pokok-pokok temuan penting

3. Disusun penyajian data yang sistematis dengan disunting agar lebih mudah dipahami. Dilengkapi dengan faktor pendukung seperti metode, skema, bagan dan tabel.

4. Kemudian dirumuskan kesimpulan sementara yang dapat berkembang sejalan dengan penemuan data dan pemahaman baru, sehingga akan didapatkan suatu kesimpulan yang mantap dan sesuai dengan fakta hingga dapat ditemukan dan dirumuskan kesimpulan akhir.

\section{F. Pembahasan}

Dalam penelitian tentang Strategi Fakultas Dakwah Dan Ilmu Komunikasi Dalam Mewujudkan Kampus Yang Berkarakter, peneliti dapat menyimpulkan strategi yang disusun oleh organisasi telah terpadu pada tiga kegiatan dalam proses pendidikan yaitu : kegiatan pembelajaran, kegiatan ko-kurikuler dan ekstrakurikuler, serta kegiatan pembiasaan, yaitu :

\section{Kegiatan Pembelajaran}

Pengembangan karakter dalam kegiatan belajar mengajar di ruang perkuliahan, direncanakan dengan menggunakan pendekatan terintegrasi dalam semua mata kuliah. Terdapat beberapa matakuliah antara lain, Pendidikan Kewarganegaraan, Pancasila, Akhlak Tasawuf, Character Building yang misi utamanya adalah mengembangkan nilai dan sikap mahasiswa dengan menggunakan berbagai strategi pengembangan karakter agar memiliki dampak 
langsung dan dampak pengiring melalui pengalaman belajar tertentu. Sementara mata kuliah yang lain, yang secara formal memiliki misi utama selain pengembangan karakter, wajib mengembangkan rancangan pembelajaran semester pendidikan karakter yang diintegrasikan kedalam substansi atau kegiatan mata kuliah sehingga memiliki dampak langsung dan sekaligus mengiringi perkembangan mahasiswa.

Dalam mengorganisir situasi perkuliahan di kelas, pengembangan karakter yang dilakukan menggunakan pendekatan kontekstual sebagai konsep belajar mengajar yang membantu dosen dan mahasiswa sebagai mahasiswa untuk mampu mengaitkan antara materi yang diajarkan dengan situasi dan pengalaman dunia nyata, sehingga mahasiswa dapat membuat hubungan antara pengetahuan yang dimiliki dengan penerapan langsung dalam kehidupan sehari-hari.

Evaluasi rancangan didapatkan bahwa proses pembelajaran pada dasarnya merupakan pemberian stimulus-respons yang ideal antara pendidik dan mahasiswa. Kesediaan dan kesiapan mahasiswa dalam mengikuti proses demi proses dalam perkuliahan akan menimbulkan respons yang baik terhadap stimulus yang diterima dalam proses belajar dikelas. Respons akan kuat kepada mahasiswa ketika stimulus yang diberikan oleh dosen juga kuat. Pengulangan terhadap stimulus-respons yang kuat akan memberikan kesan yang kuat sehingga secara otomatis akan dapat mempertahankan respons kedalam memori, terlebih jika dapat menghasilkan hal-hal yang menyenangkan atau mengesankan bahkan luar bisa buat para mahasiswa. Efek menyenangkan ini akan membuat mahasiswa dapat me-recall apa yang diperoleh dalam perkuliahan tanpa mengalami hambatan apapun. Kondisi ini tidak mudah diwujudkan secara merata dan keseluruhan, tetapi harus selalu dipersiapkan dan diciptakan oleh sedemikian rupa oleh dosen pengampu mata kuliah sebagai tenaga pendidik, agar mahasiswa mempunyai motivasi yang kuat untuk mengikuti perkuliahan dan dapat mengaplikasin dalam kehidupan, sebagai individu yang berkarakter.

\section{Kegiatan Ekstrakurikuler}

Kegiatan ekstrakurikuler merupakan kegiatan kampus yang bersifat umum dan terkait dengan berbagai kuliah. Kegiatan ekstrakurikuler di lingkungan IAIN Padangisidmpuan yang diikuti oleh mahaisswa Fakultas Dakwah dan Ilmu 
Komunikasi meliputi Pramuka, Sanggar Peneliti, Sanggar Diskusi, Pencinta Alam, Sanggar olahraga dan seni budaya, yang seluruhnya perlu dikembangkan secara terprogram dan berkelanjutan. Kegiatan tersebut juga dilakukan melalui proses pembiasan dan penguatan dalam rangka pengembangan karakter. Kegiatan ekstrakurikuler di bidang olahraga, seni, dan keterampilan dilakukan dalam bentuk pembelajaran, pelatihan, kompetisi atau festival. Berbagai kegiatan olahraga dan seni berorientasi utama untuk penanaman dan pengembangan sikap, perilaku, karakter dan kepribadian mahasiswa agar menjadi manusia Indonesia yang baik seperti : jiwa sportif, kreatif, kerjasama, kebanggaan, disiplin, toleransi terhadap orang lain/kelompok lain, berjiwa besar dan bertanggungjawab.

Demi tercapainya kegiatan ekstrakurikuler yang mendukung program Pengembangan Karakter, perlu didukung dengan perangkat pedoman pelaksanaan, pengembangan kapasistas sumber daya manusia melalui pelatihan berbasis karakter, dan revitalisasi kegiatan kokurikuler dan ekstrakurikuler yang telah ada lebih terfokus kepada arah pengembangan karakter mahasiswa.

\section{Kegiatan Pembiasaan}

Kegiatan pembiasaan dalam lingkungan kampus dilaksanakan melalui strategi : (a) Kegiatan rutin, dilakukan bersama mahasiswa secara terus menerus dan konsisten setiap saat agar menjadi kebiasaan yang positif. Seperti melaksanakan kegiatan Character Building setiap hari rabu pagi, setiap mahasiswa yang bertugas menerima amanah yang diberikan penuh tanggungjawab dengan sebaik-baiknya. Mengunakan pakaian yang seragam dan memelihara ketertiban dan kekompakan dalam setiap pelaksanaan di lapangan Fakultas Dakwah dan Ilmu Komunikasi. (b) Kegiatan spontan, dilakukan langsung pada saat itu juga seperti kesediaan untuk mengumpulkan sumbangan ketika ada mahasiswa atau orangtua mahasiswa yang mengalami musibah, atau pemberian sumbangan untuk masyarakat ketika terjadi bencana alam di lingkungan sekitar atau bahkan di daerah lain. (c) Keteladanan, merupakan perilaku dan sikap dosen serta pegawai dalam memberikan contoh melalui berbagai tindakan yang baik sehingga diharapkan dapat menjadi panutan atau role model bagi mahasiswa lainnya. Sikap serta perilaku berkarakter yang ditunjukkan antara lain: berpakaian sesuai dengan kode etik dosen dan mahasiswa, 
menunjukkan perilaku sopan santun, disiplin, kebersihan dan kerapihan, jujur, kerja keras dan lain sebagainya. (d) Pengkondisian yaitu penciptaan kondisi yang mendukung terlaksananya Pengembangan Karakter, misalnya pegawai bagian Umum yang mempersiapkan kondisi parkiran kendaraan mahasiswa yang rapi dan aman, tersedianya tempat sampah hingga poster semboyan atau kata-kata bijak yang dipajang di berbagai lorong gedung perkuliahan. Lingkungan kampus juga ditata dengan baik agar situasi lingkungan fisik dan sosial kultural yang ada memungkinkan seluruh civitas akademika khususnya mahasiswa terbiasa melakukan kegiatan keseharian di kampus yang mencerminkan perwujudan karakter yang ingin dicapai. Strategi ini ditempuh dengan melakukan pembiasaan dan pembudayaan aspek-aspek karakter dalam kehidupan keseharian di kampus dengan pendidik sebagai figur teladan bagi mahasiswa.

\section{G. Kesimpulan}

Kegiatan Pengembangan Karakter di Fakultas Dakwah dan Ilmu Komunikasi IAIN Padangsidimpuan sesungguhnya telah disusun secara strategik sesuai dengan Rencana Strategis IAIN Padangsidimpuan yang diturunkan kedalam Renstra fakultas Dakwah dan Ilmu Komunikasi mengenai Pengembangan Karakter Islami. Strategi ini telah berjalan secara berkelanjutan namun belum terlaksana dengan sistemik, sehingga tidak memiliki dampak yang signifikan terhadap pengembangan karakter mahasiswa seperti yang diharapkan. Kegiatan pengembangan karakter hendaknya dirumuskan dalam kurikulum secara terpadu, diterapkan melalui model pendidikan yang teruji, dan dipraktekkan dalam sistem pembelajaran dengan pola kebiasaan. Selain itu dilingkungan masyarakat dan juga keluarga civitas akademika juga sebaiknya diterapkan pola pengembangan karakter. Dengan begitu, generasi muda yang unggul, cerdas dan berintegritas dapat dilahirkan melalui sistem pengembangan karakter di Fakultas Dakwah dan Ilmu Komunikasi IAIN Padangsidimpuan. 


\section{Daftar Pustaka}

Muslich, Masnur. Pengembangan Karakter, Menjawab Tantangan Krisis Multidimensional. Penerbit Bumi Aksara. Cetakan kedua, September 2011.

Masrukhin. Model Pembelajaran Character Building dan Implikasinya Terhadap Perilaku Manusia. gusmasrukhin@gmail.com. Download pada tanggal 03 Maret 2016.

Gunawan, Heri. Pengembangan Karakter, Konsep dan Implementasi. Penerbit Alfabeta. Maret 2014

Lickona, Thomas. Educating For Character: How Our Schools Can Teach Respect and Resposibility. Penerbit Bumi Aksara. Edisi 1 Cetakan ketiga. November 2013.

Najib dkk. Manajemen Strategik Pendidikan Karakter. Penerbit Gava Media. Yogyakarta. Cetakan I, 2016

Komalasari, Kokom dan Didin Saripudin. Pendidikan Karakter. Penerbit Reflika Aditama. Bandung. Cetakan Kesatu. September 2017

Bangun, Wilson. Intisari Manajemen. Penerbit Reflika Aditama. Cetakan Kedua, September 2011. 